\title{
A New Chemosensing Ensemble for Colorimetric Detection of Oxalate in Water
}

\author{
Li-Jun Tang* and Ming-Hui Liu \\ College of Chemistry and Chemical Engineering, Liaoning Key Laboratory for the Synthesis and Application \\ of Functional Compounds, Bohai University, Jinzhou 121013, P. R. China. E-mail: lijuntang@tom.com \\ Received August 9, 2010, Accepted August 19, 2010
}

\begin{abstract}
To realize highly selective recognition of oxalate in water, a new chemosensing ensemble that behaves highly selective colorimetric recognition of oxalate in water at $\mathrm{pH} 7.4$ has been developed. The ensemble was constructed by a pyrrole containing mononuclear copper complex and chromeazurol S. The ensemble shows a highly selective recognition of oxalate through an obvious color change from blue to yellow upon the addition of oxalate, whereas, other dicarboxylates such as malonate, succinate, fumarate, maleate, glutarate, adipate, phthalate, isophthalate and terephthalate do not induce any noticeable color changes. The oxalate recognition process is not significantly affected by other coexisting dicarboxylate.
\end{abstract}

Key Words: Chemosensing ensemble, Oxalate, Colorimetric detection

\section{Introduction}

Recently, considerable attention have been paid to the development of chemosensors for biologically important anions due to their fundamental roles in a wide range of chemical, environmental and biological processes. ${ }^{1-6}$ Colorimetric sensing of a specific anion is a particularly attractive research topic because of its simplicity and naked eyes detectable nature, which allows visual detection of anions without resort to expensive spectroscopic instrumentation. ${ }^{1,2,7-21}$

Dicarboxylates are among the most attractive targets for anion recognition and sensing due to their critical roles in numerous metabolic processes such as the generation of highenergy phosphate bonds and the biosynthesis of important intermediates. ${ }^{22,23}$ Detection of oxalate is particularly useful in food chemistry and in clinical analysis. For instance, the level of oxalate in urine is an indicator of calcium oxalate kidney stones. ${ }^{24}$ Although a vast number of artificial receptors for dicarboxylates have been developed during the past decade, ${ }^{25-34}$ very few examples of optical sensors for oxalate have been reported to date. ${ }^{35,36}$ Thus, there is an urgent need to develop new watersoluble artificial receptors for the detection of oxalate under physiological conditions.

Among the important design principles for anion sensing, the chemosensing ensemble approach is relatively new and simple, which is based on competitive binding of an indicator and an analyte to a receptor. ${ }^{37-42}$ In this protocol, a signaling unit (indicator) is bound to a binding site (receptor) by noncovalent interactions to form a chemosensing ensemble, which avoid the complicated synthetic process to chemically link an indicator and a receptor, thus one can focus on design of receptors having complementary shape with the target anion. Generally, it is challenging to develop receptors that bind tightly, reversibly and selectively to small molecules in water for sensing purposes. ${ }^{43}$ It has been demonstrated that some carefully designed metallic receptors can bind a target anion selectively and tightly in water. ${ }^{35,41,44}$

Herein, we developed a new chemosensing ensemble for colorimetric detection of oxalate in water at physiological $\mathrm{pH}$. The ensemble was constructed by copper complex CuL (Scheme 1) and chromeazurol S (3), which showed a high selectivity toward oxalate over other dicarboxylates.

\section{Structure of 3}

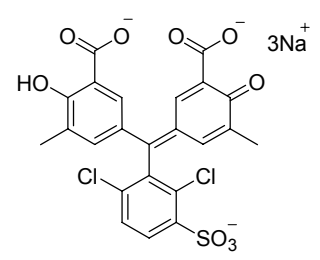

3
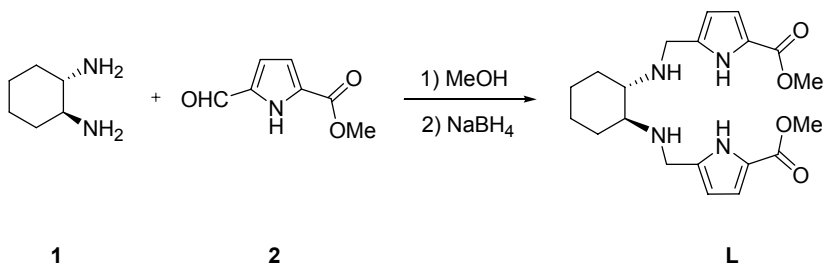

$\mathbf{L}$

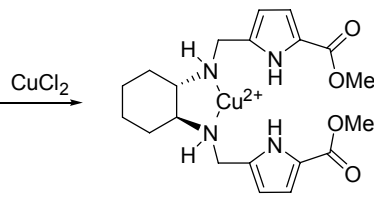

CuL

Scheme 1. Synthesis of copper complex CuL 


\section{Experimental Section}

Compound 2 was prepared according to literature procedure. ${ }^{45,46}$ All other reagents were purchased from commercial sources and used without further purification. ${ }^{1} \mathrm{H}$ NMR spectra and ${ }^{13} \mathrm{C}$ NMR spectra were obtained on a Varian INOVA$400 \mathrm{MHz}$ and Bruker AV-300 MHz Spectrometer, respectively. High-resolution mass spectrometry (HRMS) was carried out on a UPLC/Q Tof mass spectrometer. UV spectra were measured on a UV-2550 spectrophotometer.

Preparation of compound $\mathrm{L}$. To a $50 \mathrm{~mL}$ round bottom flask were added 1 (150 mg, $1.31 \mathrm{mmol})$ and $\mathbf{2}(500 \mathrm{mg}, 3.27 \mathrm{mmol})$. These were dissolved in anhydrous methanol $(20 \mathrm{~mL})$ and the reaction mixture was stirred under a nitrogen atmosphere for $6 \mathrm{~h}$ at room temperature. Then the reaction mixture was cooled to $0{ }^{\circ} \mathrm{C}$ and $\mathrm{NaBH}_{4}$ ( $160 \mathrm{mg}, 4.10 \mathrm{mmol}$ ) was added portionwise during $1 \mathrm{~h}$, and the reaction mixture was allowed to stir for further $1 \mathrm{~h}$. After the completion of the reaction, the solvent was removed under reduced pressure to give a white residue, which on recrystallization from ethyl acetate-hexane $(1: 19, \mathrm{v} / \mathrm{v})$ gave $\mathbf{L}$ as white solid. Yield: $77 \%$. mp $107-108^{\circ} \mathrm{C}$. ${ }^{1} \mathrm{H}$ NMR (400 MHz, $\left.\mathrm{CDCl}_{3}\right) \delta 6.83(\mathrm{~d}, J=3.6 \mathrm{~Hz}, 2 \mathrm{H}), 5.97$ $(\mathrm{d}, J=3.6 \mathrm{~Hz}, 2 \mathrm{H}), 4.26(\mathrm{~d}, J=16 \mathrm{~Hz}, 2 \mathrm{H}), 4.01(\mathrm{~d}, J=16 \mathrm{~Hz}$, 2H), $3.78(\mathrm{~s}, 6 \mathrm{H}), 2.24(\mathrm{~d}, J=9.2 \mathrm{~Hz}, 2 \mathrm{H}), 2.18(\mathrm{~d}, J=13.2 \mathrm{~Hz}$, 2H), $1.81(\mathrm{~b}, 4 \mathrm{H}), 1.72(\mathrm{~d}, J=8.4 \mathrm{~Hz}, 2 \mathrm{H}), 1.17(\mathrm{t}, J=10 \mathrm{~Hz}$, $2 \mathrm{H}), 1.01(\mathrm{~d}, J=8.4 \mathrm{~Hz}, 2 \mathrm{H}) .{ }^{13} \mathrm{C}$ NMR $\left(75 \mathrm{MHz}, \mathrm{CDCl}_{3}\right) \delta$ 163.4, 137.5, 121.4, 116.2, 106.8, 61.4, 51.1, 43.6, 32.9, 25.2. HRMS (ESI+): calcd for $\mathrm{C}_{20} \mathrm{H}_{29} \mathrm{~N}_{4} \mathrm{O}_{4}[\mathbf{L}+\mathrm{H}]^{+} 389.2189$, found 389.2193.

Preparation of complex CuL. To a solution of $\mathbf{L}(100 \mathrm{mg}$, $0.26 \mathrm{mmol}$ ) in $5 \mathrm{~mL}$ ethanol, ethanolic solution of $\mathrm{CuCl}_{2}$. $2 \mathrm{H}_{2} \mathrm{O}$ (56 mg, $0.33 \mathrm{mmol}$ ) was added at room temperature, the mixture was stirred for $1 \mathrm{~h}$. The blue precipitate formed was filtered and washed thoroughly with cold diethyl ether. The product $\mathrm{CuL}$ was isolated in $70 \%$ yield $(102 \mathrm{mg})$. ESI-TOF MS: calcd for $\mathrm{C}_{20} \mathrm{H}_{27} \mathrm{CuN}_{4} \mathrm{O}_{4}[(\mathrm{~L}-\mathrm{H}) \mathrm{Cu}]^{+} 450.1317$, found 450.2875 .

\section{Results and Discussion}

After screening several of colorimetric indicators for chemosensing ensemble, chromeazurol S (3) was finally selected for this research. First, the UV-vis absorption changes of $3(1.0 \times$ $10^{-5} \mathrm{M}$ ) toward CuL in a HEPES (4-(2-hydroxyethyl)-1-piperazineethanesulfonic acid, $10 \mathrm{mM})$ buffer $\left(\mathrm{pH} \mathrm{7.4)}\right.$ at $25^{\circ} \mathrm{C}$ was investigated (Fig. 1). With a gradual increase in the concentration of $\mathbf{C u L}$, the absorption band of $\mathbf{3}$ centered at $426 \mathrm{~nm}$ gradually decreased, simultaneously, a new absorption band centered at $606 \mathrm{~nm}$ was formed and developed, accompanied with a significant color change from yellow to blue. A noticeable isosbestic point appeared at $500 \mathrm{~nm}$ can be observed, which indicated the formation of a stable complex between $\mathbf{C u L}$ and 3 . When 10 equiv of $\mathbf{C u L}$ was added to $\mathbf{3}$ solution, the UV-vis absorption changes were completely saturated. Nonlinear leastsquares fitting of the titration profiles (inset in Fig. 1, absorbance at $606 \mathrm{~nm}$ ) was consistent with the formation of a 1:1 receptor-indicator complex (the correlation coefficient is over 0.99 ), and the binding constant $K_{\mathrm{s}}$ was calculated to be $1.01 \times$ $10^{4} \mathrm{M}^{-1}$. The equation used was:

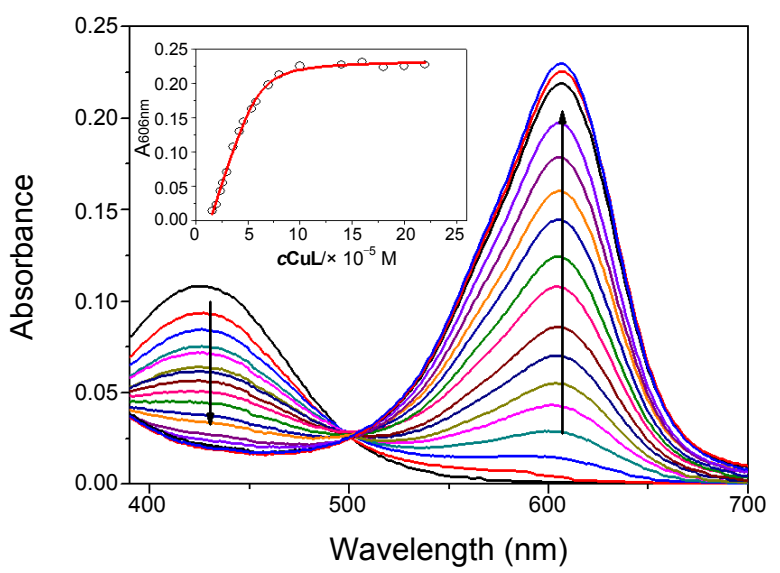

Figure 1. UV-vis absorption changes of $\mathbf{3}\left(1.0 \times 10^{-5} \mathrm{M}\right)$ upon the addition of CuL. All were water solutions buffered by HEPES ( $10 \mathrm{mM}$, pH 7.4). Inset: nonlinear least-squares fitting curve.

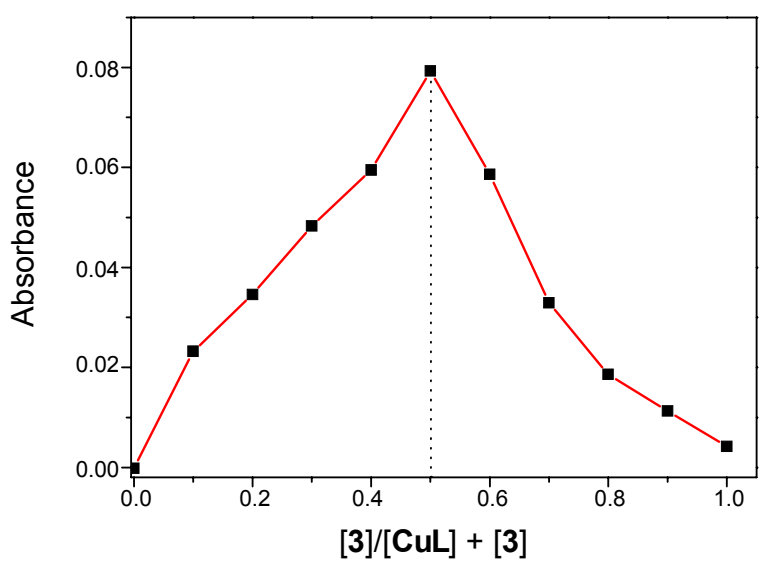

Figure 2. Job plot of CuL with $\mathbf{3}$ (at $606 \mathrm{~nm}$ ). The total concentration of CuL and 3 is $5.0 \times 10^{-5} \mathrm{M}$.

$A=A_{0}+0.5 \Delta \varepsilon\left\{C_{L}+C_{M}+1 / K_{\mathrm{s}}-\left[\left(C_{L}+C_{M}+1 / K_{\mathrm{s}}\right)^{2}-4 C_{\mathrm{M}} C_{\mathrm{L}}\right]^{1 / 2}\right\}$

Where $A$ represents the recorded absorbance, $A_{0}$ represents the start value without addition of $\mathrm{CuL}, \Delta \varepsilon$ is the change in molar extinction coefficient, $C_{M}$ and $C_{L}$ represent the concentration of $\mathbf{C u L}$ and $\mathbf{3}$, respectively. $K_{S}$ is the binding constant between $\mathbf{C u L}$ and 3.

The 1:1 binding stoichiometry of $\mathbf{C u L}$ and $\mathbf{3}$ was further proved by Job's plot according to the continuous variation methods with a total concentration of $[\mathbf{C u L}]+[3]$ as $5.0 \times 10^{-5} \mathrm{M}$ (Fig. 2). The absorbance at $606 \mathrm{~nm}$ reached a maximum when the molar fraction of $\mathbf{3}$ was 0.5 , which also demonstrated the 1:1 binding stoichiometry of CuL and $\mathbf{3}$.

Then absorbance changes of the prepared chemosensing ensemble (water solution containing $3\left(1.0 \times 10^{-5} \mathrm{M}\right)$ and $\mathbf{C u L}$ $\left(1.0 \times 10^{-4} \mathrm{M}\right)$ buffered by HEPES, $\left.10 \mathrm{mM}, \mathrm{pH} 7.4\right)$ upon the addition of some commonly existing dicarboxylates were examined (for each anion, 50 equiv to 3 of the sodium salt was used), and the results were depicted in Fig. 3. Among the tested dicarboxylates, only oxalate is able to induce significant absorption changes, which indicates the successful displacement of $\mathbf{3}$ from the receptor-indicator pair, this also can be proved 


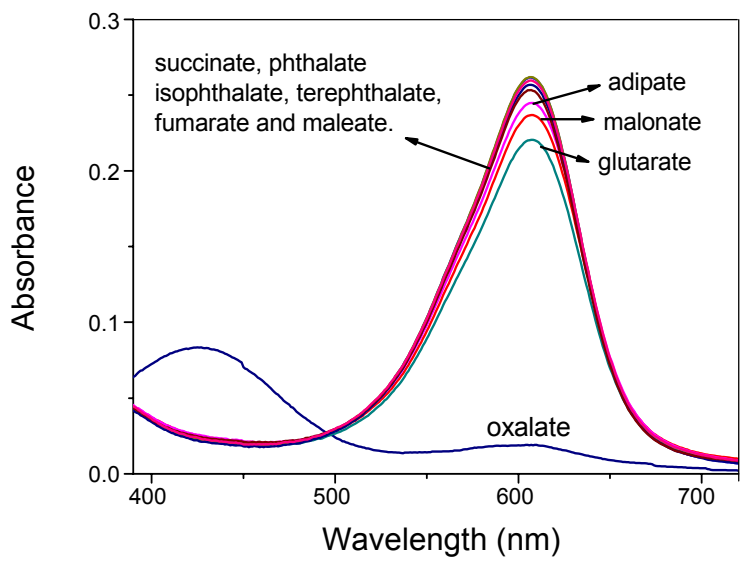

Figure 3. UV-vis absorption changes of the ensemble upon the addition of different dicarboxylates (50 equiv to 3 ) in HEPES buffered (10 mM, pH 7.4) water solution.

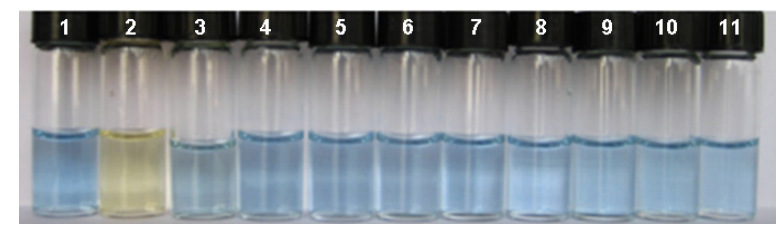

Figure 4. Color changes of the ensemble upon the addition of different dicarboxylates in HEPES buffered (10 mM, $\mathrm{pH} 7.4)$ water solution. 1. ensemble, 2 . oxalate, 3 . malonate, 4 . succinate, 5 . glutarate, 6 . adipate, 7. phthalate, 8 . isophthalate, 9 . terephthalate, 10 . fumarate, 11 . maleate ( 50 equiv to 3 was used for each dicarboxylate).

by visual detection (Fig. 4). Whereas, no noticeable absorption changes were observed upon the addition of other surveyed dicarboxylates such as malonate, succinate, fumarate, maleate, glutarate, adipate, phthalate, isophthalate and terephthalate. These results demonstrated that the chemosensing ensemble has a high selectivity toward oxalate.

The UV-vis absorption changes of the ensemble upon the addition of different amount of oxalate were illustrated in Fig. 5. Upon incremental addition of oxalate to the solution of ensemble, the UV-vis absorption curves increased at $426 \mathrm{~nm}$ and decreased at $606 \mathrm{~nm}$, the absorption at $426 \mathrm{~nm}$ reached saturation when 100 equiv of oxalate (relative to 3 ) was added. The binding constant between oxalate and $\mathrm{CuL}$ was measured to be $K_{\mathrm{a}}=1.85 \times 10^{4} \mathrm{M}^{-1}$ by fitting the data with a standard method for competition assays. 47,48

To further verify the high selectivity of CuL toward oxalate, the competition experiments in the presence of potentially competitive dicarboxylates were also carried out. As shown in Fig. 6, except oxalate, other dicarboxylates (100 equiv to 3) do not produce dramatic absorption decrease at $606 \mathrm{~nm}$. Nevertheless, upon the addition of oxalate ( 50 equiv to 3 ) to the solution containing ensemble and other dicarboxylate, a significant decrease in absorption at $606 \mathrm{~nm}$ is observed. These results revealed that the recognition of oxalate by this ensemble is not significantly influenced by other coexisting dicarboxylate, therefore, the ensemble exhibits a very high selectivity toward oxalate.

For potential applicability of the chemosensing ensemble, the effect of $\mathrm{pH}$ on absorbance (at $606 \mathrm{~nm}$ ) of the ensemble in

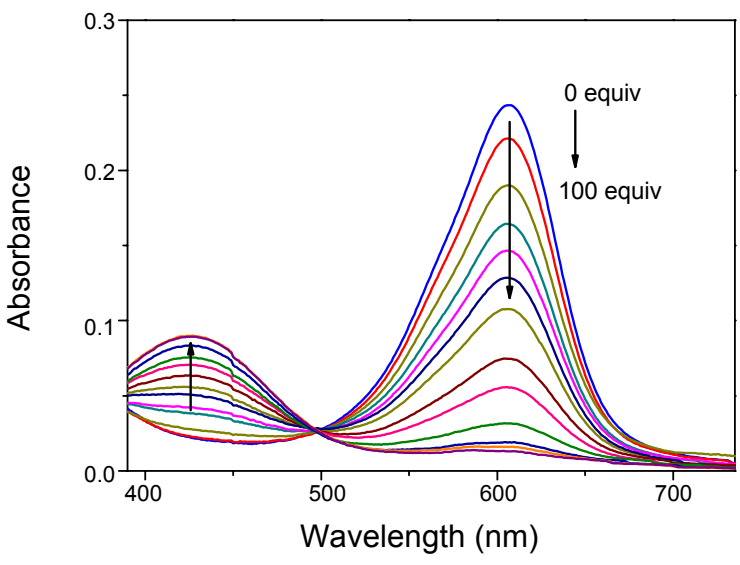

Figure 5. UV-vis absorption changes of the ensemble upon the addition of different amount of oxalate $(0-100$ equiv to 3$)$. All were water solutions buffered by HEPES (10 mM, pH 7.4).

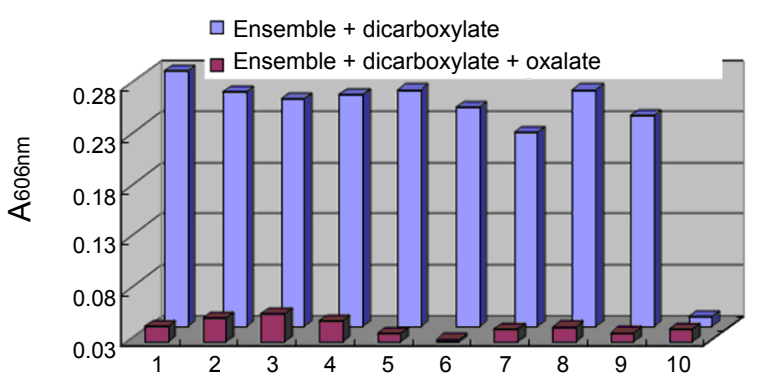

Figure 6. UV-vis absorption changes of the ensemble in the presence of potentially competitive dicarboxylates. 1 . fumarate; 2 . maleate; 3 . terephthalate; 4 . isophthalate; 5 . phthalate; 6 . adipate; 7 . glutarate; 8 . succinate; 9 . malonate; 10 . oxalate.

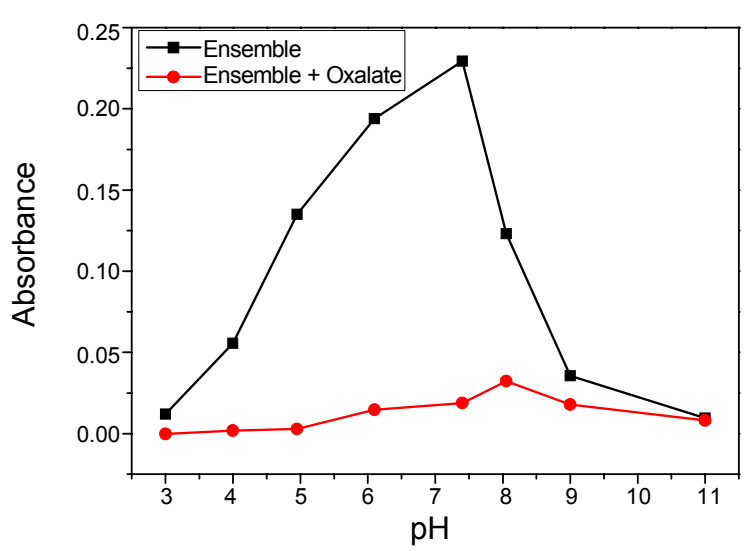

Figure 7. Effect of $\mathrm{pH}$ on absorbance (at $606 \mathrm{~nm}$ ) of the ensemble (black square) and ensemble + oxalate solutions (red dot).

both the absence and presence of oxalate was also investigated. As shown in Fig. 7, the absorbance of the ensemble decreased significantly under both strong acidic and basic conditions compared with that under near neutral conditions. After addition of oxalate (50 equiv to 3 ), the absorbance of the ensemble solutions decreased remarkably and showed very weak absorbance. These results revealed that dramatic changes in absorbance of the ensemble before and after addition of oxalate only can be 
obtained under near neutral conditions. Thus, oxalate recognition by this ensemble in water is applicable under near neutral conditions.

\section{Conclusion}

In summary, we have presented a new chemosensing ensemble that exhibits high selectivity toward oxalate in $100 \%$ aqueous solution at physiological $\mathrm{pH}$. The readily prepared chemosensing ensemble can effectively differentiate oxalate from other dicarboxylates such as malonate, succinate, fumarate, maleate, glutarate, adipate, phthalate, isophthalate and terephthalate. The recognition of oxalate is hardly affected by those commonly coexisted dicarboxylates.

Acknowledgments. We are grateful to the Natural Science Foundation of Liaoning Province of China for financial support (No: 20102004).

\section{References}

1. Martínez-Máñez, R.; Sancenón, F. Chem. Rev. 2003, 103, 4419.

2. Suksai, C.; Tuntulani, T. Chem. Soc. Rev. 2003, 32, 192.

3. Beer, P. D.; Gale, P. A. Angew. Chem. Int. Ed. 2001, 40, 486.

4. Wallington, T. J.; Kaiser, E. W.; Farrell, J. T. Chem. Soc. Rev. 2006, 35,335 .

5. Gale, P. A. Acc. Chem. Res. 2006, 39, 465.

6. Fabbrizzi, L.; Licchelli, M.; Rabaioli, G.; Taglietti, A. Coord. Chem. Rev. 2000, 205, 85.

7. Niikura, K.; Metzger, A.; Anslyn, E. V. J. Am. Chem. Soc. 1998 120,8533

8. Aït-Haddou, H.; Wiskur, S. L.; Lynch, V. M.; Anslyn, E. V. J. Am. Chem. Soc. 2001, 123, 11296.

9. Leung, D.; Folmer-Andersen, J. F.; Lynch, V. M.; Anslyn, E. V. J. Am. Chem. Soc. 2008, 130, 12318.

10. Folmer-Andersen, J. F.; Lynch, V. M.; Anslyn, E. V. J. Am. Chem. Soc. 2005, 127, 7986.

11. Vázquez, M.; Fabbrizzi, L.; Taglietti, A.; Pedrido, R. M.; González-Noya, A. M.; Bermejo, M. R. Angew. Chem. Int. Ed. 2004, 43, 1962.

12. Lin, Y. S.; Tu, G. M.; Lin, C. Y.; Chang, Y. T.; Yen, Y. P. New. J. Chem. 2009, 33, 860 .

13. Kato, R.; Nishizawa, S.; Hayashita, T.; Teramae, N. Tetrahedron Lett. 2001, 42, 5053 .

14. Yen, Y. P.; Ho, K. W. Tetrahedron Lett. 2006, 47, 1193.

15. Quinlan, E.; Matthews, S. E.; Gunnlaugsson, T. Tetrahedron Lett. 2006, 47, 9333.

16. Zhou, L. L.; Sun, H.; Li, H. P.; Wang, H.; Zhang, X. H.; Wu, S. K.; Lee, S. T. Org. Lett. 2004, 6, 1071.

17. Choi, M. K.; Kim, H. N.; Choi, H. J.; Yoon, J.; Hyun, M. H. Tetra hedron Lett. 2008, 49, 4522.

18. Shao, J.; Lin, H.; Lin, H. K. Talanta 2008, 75, 1015.

19. Kim, H.-J.; Asif, R.; Chung, D. S.; Hong, J.-I. Tetrahedron Lett. 2003, 44, 4335.

20. Ryu, D.; Park, E.; Kim, D.-S.; Yan, S.; Lee, J. Y.; Chang, B.-Y.; Ahn, K. H. J. Am. Chem. Soc. 2008, 130, 2394.

21. Kim, H.; So, S. M.; Yen, C. P.; Vinhato, E.; Lough, A. J.; Hong, J.-I.; Kim, H.-J.; Chin, J. Angew. Chem. Int. Ed. 2008, 47, 8657.

22. Kral, V.; Andrievsky, A.; Sessler, J. L. J. Am. Chem. Soc. 1995, 117, 2953.

23. Gunnlaugsson, T.; Davis, A. P.; O'Brien, J. E.; Glynn, M. Org. Lett. 2004, 4, 2449.

24. Robertson, W. G.; Hughes, H. Scanning Microsc. 1993, 3, 391.

25. Liu, S. Y.; Fang, L.; He, Y. B.; Chan, W. H.; Yeung, K. T.; Cheng, Y. K.; Yang, R. H. Org. Lett. 2005, 7, 5825.

26. Zeng, Z. Y.; He, Y. B.; Wu, J. L.; Wei, L. H.; Liu, X.; Meng, L. Z.; Yang, X. Eur. J. Org. Chem. 2004, 2888.

27. Raker, J.; Glass, T. E. J. Org. Chem. 2002, 67, 6113.

28. Linton, B. R.; Goodman, M. S.; Fan, E.; Arman, S. A.; Hamilton, A. D. J. Org. Chem. 2001, 66, 7313.

29. Ghosh, K.; Saha, I.; Masanta, G.; Wang, E. B.; Parish, C. A. Tetrahedron Lett. 2010, 51, 343.

30. Ghosh, K.; Masanta, G.; Chattopadhyay, A. P. Eur. J. Org. Chem. 2009, 4515

31. Singh, N.; Lee, G. W.; Jang, D. O. Tetrahedron 2008, 64, 1482.

32. Moriuchi, T.; Yoshida, K.; Hirao, T. Org. Lett. 2003, 5, 4285.

33. Ghosh, K.; Masanta, G. Tetrahedron Lett. 2008, 49, 2592.

34. Goswami, S.; Dey, S.; Jana, S. Tetrahedron 2008, 64, 6358.

35. Tang, L. J.; Park, J.; Kim, H. J.; Kim, Y.; Kim, S. J.; Chin, J.; Kim, K. M. J. Am. Chem. Soc. 2008, 130, 12606.

36. Fabbrizzi, L.; Licchelli, M.; Mancin, F.; Pizzeghello, M.; Rabaioli, G.; Taglietti, A.; Tecilla, P.; Tonellato, U. Chem. Eur. J. 2001, 7, 94 .

37. Wiskur, S. L.; Ait-Haddou, H.; Lavigne, J. J.; Anslyn, E. V. Acc. Chem. Res. 2001, 34, 963.

38. Wright, A. T.; Anslyn, E. V. Chem. Soc. Rev. 2006, 35, 14.

39. Zhu, L.; Zhong, Z. L.; Anslyn, E. V. J. Am. Chem. Soc. 2005, 127,4260 .

40. Nguyen, B. T.; Anslyn, E. V. Coord. Chem. Rev. 2006, 250, 3118.

41. Boiocchi, M.; Bonizzoni, M.; Fabbrizzi, L.; Piovani, G.; Taglietti, A. Angew. Chem. Int. Ed. 2004, 43, 3847.

42. Boiocchi, M.; Bonizzoni, M.; Moletti, A.; Pasini, D.; Taglietti, A. New. J. Chem. 2007, 31, 352.

43. Lee, J. H.; Park, J.; Lah, M. S.; Chin, J.; Hong, J.-I. Org. Lett. 2007, 9, 3729.

44. Tang, L. J.; Li, Y.; Zhang, H.; Guo, Z. L.; Qian, J. H. Tetrahedron Lett. 2009, 50, 6844.

45. Schmuck, C.; Bickert, V.; Merschky, M.; Geiger, L.; Rupprecht, D.; Dudaczek, J.; Wich, P.; Rehm, T.; Machon, U. Eur. J. Org. Chem. 2008, 324.

46. Schmuck, C. Chem. Eur. J. 2000, 6, 709.

47. Connors, K. A. Binding Constants-the Measurement of Molecular Complex Stability; John Wiley \& Sons: New York, USA, 1987.

48. Kim, S. Y.; Hong, J.-I. Tetrahedron Lett. 2009, 50, 1951. 